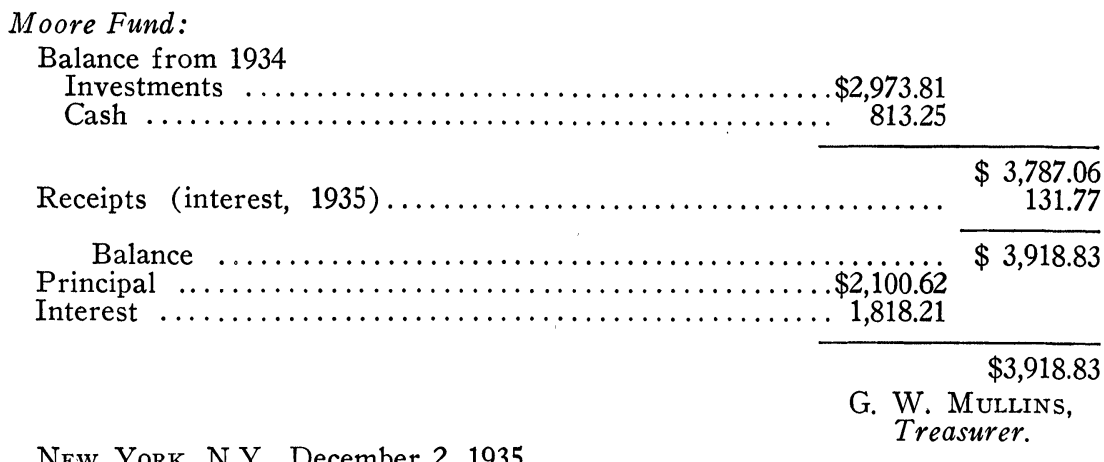

New YoRK, N.Y., December 2, 1935.

\title{
REPORT OF THE AUDITING COMMITTEE, 1935
}

We, the undersigned Auditing Committee, appointed by the American Mathematical Society, have this day audited the accounts of the Treasurer and in our opinion the following statement is correct:

\section{General Funds}

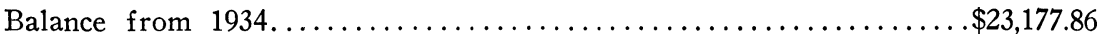

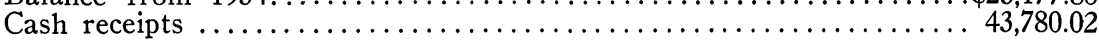

$\$ 66,957.88$

Disbursements

$35,506.13$

Balance, December 2, 1935.

$\$ 31,451.75$

Invested as follows:

Cash in Corn Exchange Bank, exclusive of outstanding checks...... \$6,724.15

Cash in Union Dime Savings Bank ............................ $3,400.72$

Cash in Bank for Savings................................ 2,620.71

Cash in Providence Bank for Savings. . . . . . . . . . . . . . . . . . . . .

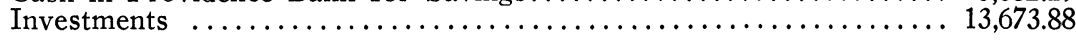

$\$ 31,451.75$

Bôcher Fund:

Special Funds

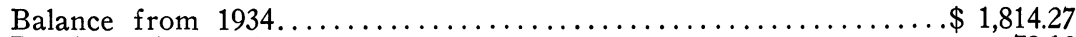

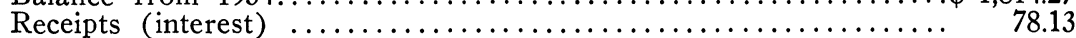

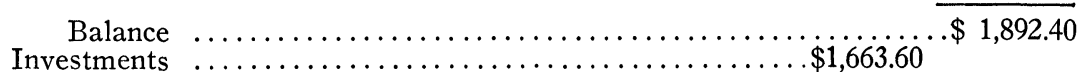

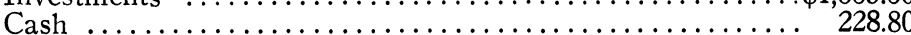

$\$ 1,892.40$

Cole Fund:

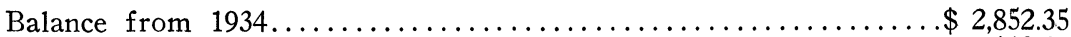

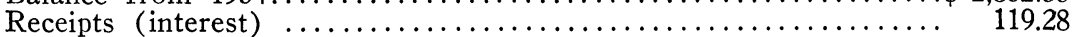

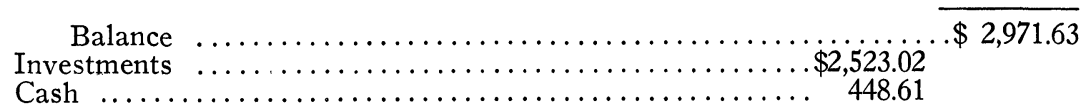


Moore Fund:

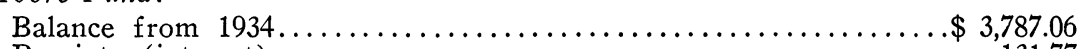

Receipts (interest) $\ldots \ldots \ldots \ldots \ldots \ldots \ldots \ldots \ldots \ldots \ldots \ldots \ldots \ldots \ldots \ldots \ldots \ldots \ldots \ldots \ldots \ldots \ldots \ldots \ldots \ldots, 131.77$

Balance

$\overline{\$ 3,918.83}$

Investments

Cash

$\$ 2,973.81$

$\$ 3,918.83$

The amount of reserve necessary to protect the life membership, is now $\$ 6,098.80$.

New YoRK, N.Y., December 12, 1935.

B. P. GILL

S. A. JoFre

Auditing Committee 